seen upon the walls of the depths where they had died. No one could know that these were the pictures drawn so many years before by Sukitori-me who saw the unseen and could foresee the future. Using only the twenty nails on his hands and feet on the dungeon walls, Sukitori-me had etched a dreadful scene-wave upon wave of dying monkeys, writhing in fear, with despair and disillusionment flaming in their eyes.

When at last the seared forest trees began once more to put forth buds, and those monkeys who had been able to escape slowly started coming back, they found the drawings on the walls. Dogs and men alike had puzzled over the figures of monkeys scratched into solid stone. The monkeys, however, understood Sukitori-me's drawings only too well, and it struck their hearts and minds with all the force of an earthquake.

In these sketches outlined with such difficulty on the dungeon walls, Sukitori-me had succeeded perfectly in expressing thoughts and feelings which cannot be described by the gibberish chatter of simian speech.

Let us word it more precisely. In attempting to describe the unseen and relate the unkown, the artist Sukitori-me was the first to make use of signs and symbols mutually intelligible to all simian beings.

With this, the story comes to an end.

If you who read this tale should ever chance to find strange signs and scratchings upon the walls of caverns or upon the stumps of long-dead trees, look at them well and think of the monkey painter Sukitori-me. Of course it will not matter if you do not remember his name. If, when you see such signs and endlessly repeating patterns, you can imagine feelings unnamable in words and think somehow of the eternal struggle between that which lives and that which belongs to death, that thought alone will be enough.

Translated by Ann Herring

N IEH HUALING / CHINA

\title{
The Several Blessings of Wang Ta-nien
}

Having served three "emperors"-his own name for his principals-the teacher Ta-nien became privileged to occupy, with his wife and children, one of the three small rows of houses behind the school. They had lived in a 
single room as cramped as a chicken coop. Now they had both a kitchen, and a bedroom containing two double beds made of bamboo, a table and two rattan chairs with legs bound with wire, a desk long unpainted, and a bookshelf, built by Ta-nien himself, out of wooden crates.

Taped to the wall mirror a schedule dangled loosely; one of the tapes had come unstuck. Every morning Ta-nien stood with his head cocked, studying his directions to himself for the day's work, his teeth clenched with determination. Yet the tape stayed unstuck and every day hung more loosely.

\section{Morning}

\section{SCHEDULE OF TA-NIEN}

6:30 a.m. I do fifty push-ups. I do deep breathing.

7:00 a.m. I listen to English lessons on the radio with English-Chinese dictionary.

7:30 a.m. I read Speeches of Chiang Kai-shek.

\section{Evening}

8:00 p.m. I read Speeches of Richard Nixon.

10:00 p.m. I listen to English lessons on the radio with Chinese-English dictionary.

11:00 p.m. I do fifty push-ups before going to bed.

To the unexpected fortune of these rooms Ta-nien's emperor quickly added two blessings-a bonus and a certificate of merit "for outstanding service":

This is to certify to the outstanding service rendered the First High School, Taipei, Taiwan, during the period from September, 1964, to August, 1965 ...

"Wen-chin!" Ta-nien cried triumphantly, bearing in his hand the certificate he'd already read aloud to his wife a dozen times, "Wen-chin! Our luck has turned at last! Who knows what fresh fortune awaits tomorrow? Let's invite the Sage to a feed!"

His four-year-old son, Little Oak, wearing a G. I. cap, began goosestepping proudly for no reason except his contentment in seeing his father victorious.

In the house below the palms the windows were steaming. Odors of urine, mild and strong soap that babies give off, mixed with the scent of frying pork, the smoke from Ta-nien's pipe, and of tea brewing.

These odors swirled between ceiling and floor, trying to find some means of escape, while beyond the window the rain, furious then fitful, tried to find some way of getting inside.

"Sage!" said Ta-nien, attempting to cheer up his old friend. "Why so forlorn? Good times are with us once more! Why, the way things are booming 
here and the way they're going to hell in a handcar over there, we'll be back on the mainland by this time next year!"

The Sage shook his head almost imperceptibly; all his movements were nearly imperceptible. The meaninglessness of years in the routine of a small provincial school had left his face meaningless: a face of no particular shape, a voice that had lost its inflection, and a smile that apologized to everyone all day long.

"We can never get those good years back," the Sage murmured, half to himself, yet casting a dulled look at Wen-chin. One of his hopes had long been to invite Ta-nien and Wen-chin to his own home for Peking duck. Every week while dining here, this hope had returned. Yet even now as he was about to say the words, he saw, in raising his wine cup, how frayed his sleeves had become. So all he said was, "To you, Wen-chin."

And as he drank, his eyes still upon her, he saw how time had marred this woman; he remembered her face flawless as the moon on a night when the sky is clear. Now crow's-feet had frayed her eyes as time had frayed his sleeves; and her belly was swollen again.

He remembered her walking a bridge between two clusters of willows. One cluster was bright in the morning; the other bright by evening. She had worn a vermilion sweater and a white silk scarf, walking toward him and twirling a twig. They had walked together down Lovebird Road.

"Stop staring at my wife, Sage," Ta-nien teased his friend good-naturedly, "You had your chance and missed it."

"I never deserved her," the Sage acknowledged; "the better man won." Although Wen-chin was perpetually angry at her husband, she never felt irritated by him; and although the Sage never angered her, everything he did irritated her.

"I can't say that between you two, I had a wide choice," she said.

"I'm eating you out of house and home," Sage apologized as he apologized every Sunday.

"There is always a place for you here, Sage," Ta-nien reassured him as he reassured him every Sunday. "Now-I wish to speak seriously: I have a plan which will make us both independent!"

The Sage wiped his chin and stopped eating out of respect for his host.

"But it is strictly confidential," Ta-nien warned his friend.

"What else?" Wen-chin put in quickly. "Wasn't the prep school confidential? Wasn't the chain of correspondence courses confidential? Wasn't the plan for a farm confidential? Perhaps this time you'd better advertise."

Ta-nien ignored his wife with practiced deliberation. His belly resting upon his crossed legs, he sat in the rattan chair confidently.

"This time we have to be resolute," he declared.

"Very resolute," the Sage agreed immediately without the faintest notion 
of his part in the newest plan. "I'm ready for The Plan," he assured Ta-nien. "Breed fish!" Ta-nien gave his idea to the waiting world.

"Breed fish?" the Sage echoed, as though it had just now occurred to him that fish reproduced.

"Fish?" Wen-chin cut in. "Are all fish the same? What fish? Eels? Salmon? Mackerel? Carp? What fish?"

"Why"-Ta-nien grinned sheepishly; it had apparently not occurred to him that there was more than one kind-"why, carp, of course," he added quickly.

"The ducks will finish off the eggs," Wen-chin decided; "hoodlums will electrify the pond to kill off what the ducks won't get. The rest will die for lack of fresh water. Your fish will starve. So will your family."

"Now for the second step," Ta-nien went on, as if his wife hadn't said a word.

"What was the first?" she demanded.

"First, we clean out the pond. Second, we fertilize it. Third, we put in the eggs. And, finally-our Sage here guards our investment day and night protecting us from ducks, vandals, and all disasters."

The Sage gave a start, paled, and recovered.

"I would have to leave the school," he reminded Ta-nien; "if it didn't work, I'd be jobless. You're asking me to take a great risk, Ta-nien."

"What? Are you going to go about with frayed sleeves all your life?"

"But, Ta-nien, I don't know how to breed fish," the Sage pleaded weakly.

"It's an age of specialization, old friend," Ta-nien assured him firmly. "Breeding of the fish will be $m y$ responsibility. Guarding them will be yours. Nothing ventured, nothing gained. OK?”

Behind her husband's back Wen-chin shook her head, slowly, sadly, yet warningly, at the Sage.

"I'll have to have a week to think it over," the Sage told Ta-nien.

"One week-but no more. We're now operating on a tight schedule, Sage," Ta-nien said. "A week is all we can let you have."

The Sage wondered who the "we" could be, but did not press the question for fear of embarrassing Ta-nien.

"Fry cost about seven cents each," Ta-nien went on. "Twenty thousand carp sell for about nineteen each in the market. But we'll sell wholesale at about ten each. Now, tell me, Sage, how many cents shall we take in by selling twenty thousand carp?"

The Sage blinked his eyes with the effort of calculation. "Two hundred thousand?"

"Two hundred thousand exactly!" Ta-nien slapped him on the shoulder in their common triumph.

"How will you get the fish to the market?" Wen-chin asked. 
Ta-nien poured wine into his own cup and then held the bottle. "One problem at a time, Madame."

"I would do it," the Sage volunteered. "But if we failed, I'd be jobless!"

"When Daddy gets money I want a whole sack of chewing gum," Little Oak said.

"And a dancing monkey as well," Wen-chin said. "You can count on your daddy. 'I do fifty push-ups,'” she mimicked him, "I read Speeches of Richard Nixon." "

"Shut the window, woman!" Ta-nien demanded.

"It is not open!" Wen-chin told him.

"Ta-nien." The Sage made him sit down in the creaking rattan chair and patted him on the shoulder. "Don't shout at her. You're a lucky dog. A pretty wife, two lovely kids."

A whimpering came from the bed. Wen-chin dropped her chopsticks and rushed to the baby. "The little devil! Wet your diaper on such an occasion!"

"She has no appreciation of me," Ta-nien complained to the Sage.

"He means he cares for nobody but himself," Wen-chin said.

"If only the world could be more like you," the Sage said as if he really meant it.

"Little Oak!" Ta-nien was encouraged to shout, “One! Two! Three! Four! One! Two! Three! Four!"

The child slipped off the chair. Twisting his head to the right, straightening his shoulders and holding his neck stiff, he began goosestepping past Ta-nien.

"He's reviewing his troops," Wen-chin told the Sage, sitting on the bed as she fed the baby.

The Sage could not refrain from laughing and coughed out the piece of pork rump he had just put in his mouth. Ta-nien, however, said abruptly: "Sage, I was thinking of our school days back on the mainland. You were really quite active."

"He was a poet," Wen-chin remembered.

"I knew a little about everything, but now can't claim to be expert in anything," the Sage admitted.

"I didn't like your dandified ways," Ta-nien recalled.

"I felt you were arrogant," the Sage remembered.

"Mama," Little Oak said, "I'm going outside. If Daddy and Uncle come to blows, call me."

"I had a right to be arrogant," Ta-nien said certainly. "Three girls chased me at one time. One was the daughter of a high-ranking official. She used to wait for me at the corner of Lovebird Road."

"How could you know she was waiting for you if you didn't cast a glance at her?" Wen-chin asked. "Turn off the gas!" 
"Ho! Look at her. She's jealous. Back then, I tell you, if I'd only given a hint, huh!" Ta-nien stopped and nodded his head vigorously.

"Little Oak, here's a piece of pig ribs for you!" Wen-chin called to the child.

He rushed in, grabbed it, took a bite, and put it down again. "Mama-too sold."

Wen-chin flung it into Ta-nien's bowl.

Ta-nien shook his head, putting on the look of an injured husband. "You see, in my wife's eye, I've become a bear in the zoo and she's the trainer."

Little Oak clapped his hands with delight and shouted: "Daddy's a bear in the zoo! Daddy's a bear in the zoo!"

Ta-nien bellowed with laughter at his own joke. Then he leaned back, and his chair collapsed with a snap. His wife, his son, and his guest rushed to the rescue. Aroused from sleep, the baby began to cry. Ta-nien struggled strenuously to stand up, but to no avail. Finally the Sage got his arms under his shoulders and raised him to his feet.

"Thank you, thank you," Ta-nien said, debating between anger and smile. Then he kicked at the ruins of the chair. "Damn it! Throw it out-I don't want to have another look at it!"

"I'd like to treat you to Peking duck next weekend," the Sage announced suddenly.

"No, Sage," Wen-chin said, holding her crying baby and patting it on the back. "Save your money and buy yourself a new suit."

"You think so little of me! I, Chen Hao ..." He approached Wen-chin with his forefinger pointing at his own nose. "I'm not a colt, am I? All these years, and nothing to show for it! But I've learned how to get an advance of a month's salary!"

"Ai-yah," Ta-nien complained, "I'm getting old. Just falling off a chair has given me an ache in the back." Ta-nien sat on the edge of the bed, tapping himself above the hips with his fist.

"What difference does it makel" The Sage waved his hand gallantly. "Here's wine, let's sing; for life's short, like the morning dew."

The rain had almost but not quite stopped when the Sage took his leave. Ta-nien and his wife saw him to the door. Under the dim streetlights the couple watched him walk to the turn in the lane.

"Sage!" Wen-chin called after him.

The Sage turned and stood waiting with his hand cocked to his ear.

"Don't let the ducks eat the fish's food!" Wen-chin shouted into the wind -and she hurried back into the house and slammed the door hard behind her.

For a long moment the two men stood looking at one another, too far apart to explain life to one another any longer. The wind in the coco palms above them whispered a warning, but neither seemed to catch its meaning. 
Finally the Sage turned off down the narrowing road. Ta-nien watched him out of sight.

The wind that once had blown through the bright willows now rose in the coco palms, chilling and cold. Between them Ta-nien saw the first lamps of evening coming on.

And turning into his own house, Ta-nien pretended to feel afraid of nothing in the whole wide windy world.

CARLOS MORAND / CHILE

\section{The Only Son}

\section{I}

Ten years passed before the Moscosos were visited by an heir. When they were married, Luciana was nineteen years old and Gaspar twenty-four. Like all couples who yield to the basic instinct of the preservation of the species, they wanted their first child without delay. But he did not come immediately; he did not come in that first year of marriage, nor in the following one, nor in the six which followed those two. Although they tried not to lose hope, at the end of the fifth year, they realized that the days were becoming rather long and empty. They looked yearningly at other people's children; and they acquired the habit of drinking together, and a little more than is prudent, considering all the time they had left to live without the presence of children. In the afternoon, as soon as Gaspar returned home from work, they took out glasses and bottles, sat in the living room, watched television and began to drink dispassionately while prolonged silences stretched between sips. The visits to his in-laws on Saturday afternoons and to her in-laws on Sunday mornings always languished soon after they began; everyone was thinking about the same thing: that it was now time for the arrival of the only one who at this height of boredom could revive by his very presence feelings dulled by habit and who could generate new topics of conversation.

After ten years of marriage, on the 15th of October, when Luciana should have been suffering the first of the four days of her menstrual period, there were no signs of its appearance. Somewhat surprised because it was the first time that this had happened, she thought that some internal disorder was temporarily altering the calendar, and she decided to wait 